\title{
Biological and mechanical characterization of commercial and experimental periodontal surgical dressings
}

\author{
Luciana Domingues \\ CONCEIÇÃO'(a) iD \\ Carlos Enrique \\ CUEVAS-SUÁREZ ${ }^{(b)}$ \\ Evandro PIVA(a) iD \\ Rafael Guerra LUND(a) \\ Fabio Renato Manzolli LEITE(c) \\ (a) Universidade Federal de Pelotas, Dental \\ School, Department of Restorative Dentistry, \\ Pelotas, RS, Brazil. \\ (b)Autonomous University of Hidalgo State, \\ Academic Area of Dentistry, Dental Materials \\ Laboratory, San Agustín, Tlaxiaca, Mexico. \\ (c)Aarhus University, Department of Dentistry \\ and Oral Health, Section of Periodontology, \\ Aarhus, Denmark.
}

Declaration of Interests: The authors certify that they have no commercial or associative interest that represents a conflict of interest in connection with the manuscript.

Corresponding Author:

Fábio Renato Manzolli Leite

E-mail: fabio@dent.au.dk

htrps://doi.org/10.1590/1807-3107bor-2021.vol35.0045

Submitted: May 11, 2020

Accepted for publication: October 8, 2020

Last revision: October 28, 2020
Abstract: The objective of this study was to evaluate the biocompatibility and mechanical properties of two commercially available and one experimental periodontal dressing materials. The cytotoxicity of Periobond $^{\circledR}$, Barricaid ${ }^{\circledR}$ and one experimental periodontal dressing based on Exothane ${ }^{\circledR} 8$ monomer was tested on 3T3/NIH mouse fibroblast. Genotoxicity was assessed by micronuclei formation, and cell alterations were analyzed using light microscopy. Both biological assays were performed using the eluate obtained from specimens after 24, 72, or 168 hours of incubation. Mechanical characterization was assessed through the ultimate tensile strength and the water sorption and solubility tests. The significance level of $\alpha=0.05$ was used for all statistical analyses. All the materials promoted a cell viability lower than $60 \%$ in all evaluated times. In general, the cell viability was significantly reduced after 72 and $168 \mathrm{~h}$ of specimens' incubation. Considering the factor material, there were not statistical differences in the cell viability $(p=0.156)$. The genotoxicity was not statistically significant among the groups in the different periods of time ( $p>0.05)$. Differences in the ultimate tensile strength values were not statistically significant different among the groups $(p=0.125)$. Periobond ${ }^{\circledR}$ showed the higher water sorption values $(\mathrm{p}<0.001)$. Regarding solubility, there were no statistical differences between the groups $(p=0.098)$. All the periodontal dressing materials evaluated in this study exerted a cytotoxic effect against mouse fibroblasts, and their toxicity became more evident over time. Among the materials evaluated, the experimental light-cure type has shown overall similar properties to the commercial references.

Keywords: Periodontal Dressings; Dental Materials; Biological Assay; Mechanical Tests; In Vitro Techniques.

\section{Introduction}

Periodontal surgery involves manipulation of the oral tissue, triggering hemorrhage and a blood clot formation, which is intended to prevent bacterial colonization to promote tissue healing. ${ }^{1}$ Due to the open wound after periodontal surgery, it is recommended to use a periodontal dressing to reduce the post-operative bleeding, protect the 
wound area, provide greater comfort to the patient and prevent the occurrence of an excessive formation of granulation tissue. ${ }^{2}$

Dental materials recommended for periodontal dressing can be grouped into three main categories: a) zinc oxide and eugenol based, b) zinc oxide without eugenol based, and c) those based in other products. ${ }^{3}$ Eugenol-containing materials have been used over the years and they have been related to the occurrence of allergic reactions inflammation, delayed wound healing, tissue necrosis, and inhibition of fibroblast proliferation. ${ }^{4}$ These overcomes lead to the development of non-eugenol dressings in the late 1950s, which are currently the most widely used periodontal dressings. ${ }^{3}$

Periodontal dressings based in other products include cyanoacrylate dressing, light-cure dressing, collagen dressing, and mucoadhesive dressing. ${ }^{3}$ Of these, especial attention has been paid to lightcured dressing materials, like Barricaid ${ }^{\circledast}$ (LD Caulk, Delaware, USA). This is a single-component material supplied in a syringe for direct placement. Due to its formulation, based on polyether urethane dimethacrylate resin, this material possesses superior physical properties such as easy handling and adequate working and setting times. ${ }^{5}$ After curing, this product has rubber-consistency, low solubility, and translucent pink color, which is esthetically pleasing. ${ }^{6}$

Despite that, the evaluation of physical properties of periodontal dressings is extremely valuable to predict the material's clinical behavior. Only a limited number of studies have evaluated the physical and mechanical properties of periodontal dressings. ${ }^{1}$ Actually, to the best of our knowledge, there are no standardized characterization techniques to evaluate new periodontal dressings.
With the introduction into the market of novel dimethacrylate monomers with elastomeric behavior, as the Exothane ${ }^{\circledR}$ elastomers, it has become feasible to develop new polymers with a low modulus of elasticity and a suitable consistency for application as gingival dressings. Hence, the aim of this study was to evaluate the biocompatibility and mechanical properties of several periodontal dressing materials, and to compare these properties with those of an experimental light-cured periodontal dressing formulated with Exothane $^{\circledast}$ elastomers. The null hypotheses to be tested was that there would be no significant differences among the properties evaluated for commercial and experimental periodontal dressings.

\section{Methodology}

\section{Experimental design and sample preparation}

The study was divided into three parts: a) formulation of experimental periodontal cement; b) biocompatibility assays of cytotoxicity and genotoxicity; and c) physical-mechanical properties (ultimate tensile strength and water sorption and solubility). Table 1 details the commercially available periodontal dressing materials tested. Experimental light-cured periodontal dressing was formulated using a resin matrix containing Exothane ${ }^{\circledR} 8$ (Esstech Inc, Essington, USA). Camphorquinone and Ethyl 4-(dimethylamino)benzoate (EDAB) were added as a photoinitiator and coinitiator, respectively (Sigma-Aldrich, Saint Luis, USA). Finally, nanometric silica Aerosil ${ }^{\circledR}$ OX80 (Evonik, Essen, Germany) was added to the resin matrix using a high-speed mixer SpeedMixer ${ }^{\mathrm{TM}}$ DAC 150.1 FV (FlackTek Inc., Buckinghamshire, UK).

Table 1. Materials used as control and their specifications.

\begin{tabular}{|c|c|c|c|}
\hline Periodontal dressing & Type & Manufacturer & Components \\
\hline $\begin{array}{l}\text { Barricaid }^{\circledR} \\
\text { Lot number: } 100721\end{array}$ & $\begin{array}{l}\text { Light-cured } \\
\text { periodontal dressing }\end{array}$ & $\begin{array}{l}\text { Caulk/Dentsply, } \\
\text { Milford, USA }\end{array}$ & $\begin{array}{l}\text { Polyether urethane dimethacrylate resin, silanated silica, VLC photo- } \\
\text { initiator and acelerator, stabilizer, colorant. }\end{array}$ \\
\hline Periobond ${ }^{\circledR}$ & $\begin{array}{l}\text { Non eugenol } \\
\text { chemically-cured }\end{array}$ & Dentsply, Petropolis, & $\begin{array}{l}\text { Base: rosin, cellulose, natural gums and waxes, liquid coconut fatty } \\
\text { acid, chlorothymol, zinc acetate, denatured alcohol, methanol, } \\
\text { petrolatum, lorothidol (a fungicide). }\end{array}$ \\
\hline Lot number: $126274 \mathrm{~B}$ & periodontal dressing & & $\begin{array}{l}\text { Accelerator: zinc oxide, vegetable oil, mineral oil, chlorothymol (an } \\
\text { antibacterial agent), silica, magnesium oxide, synthetic resin, coumarin }\end{array}$ \\
\hline
\end{tabular}


All specimens were prepared according to the manufacturers' instructions. For Barricaid ${ }^{\circledR}$ and Exothane based periodontal dressing, specimens were prepared by filling a silicon molds with the uncured materials. Then, the samples were irradiated on both sides for $20 \mathrm{~s}$ using the Ultra Radii ${ }^{\circledR}$ (SDI, Australia) light curing unit with an intensity of $900 \mathrm{~mW} / \mathrm{mm}^{2}$. For Periobond ${ }^{\circledR}$ specimens, equal parts of base and accelerator were mixed until obtaining a homogeneous paste. After mixing, the material was packed into silicon molds. The material was allowed to completely set before removing, after setting time of 3 minutes.

\section{Biological assays}

\section{Cell culture}

The cell culture medium DMEM was supplemented with 10\% fetal bovine serum (FBS), 2\% L-glutamine, penicillin (100 $\left.\mathrm{U} \mathrm{mL}^{-1}\right)$ and streptomycin (100 $\mathrm{mg} \mathrm{mL}^{-1}$ ). Mouse fibroblasts of the 3T3/NIH immortalized cell line (Cells bank of Rio de Janeiro, $\mathrm{RJ}$, Brazil) were maintained in DMEM and incubated at $37^{\circ} \mathrm{C}$ in a humidified atmosphere of $5 \% \mathrm{CO}_{2}$ until confluence.

\section{Cell viability assay}

The 3-(4,5-dimethylthiazol-2-yl)-2,5diphenyltetrazolium bromide (MTT) assay was used to assess cell metabolic function by mitochondrial dehydrogenase activity. Mouse fibroblasts 3T3/NIH immortalized cell line was cultivated and the cell density was adjusted to $2 \times 10^{4} /$ well. Cells were inoculated into triplicate wells of 96 -well plates at $200 \mu \mathrm{L}$ per well and incubated for $24 \mathrm{~h}$ at $37^{\circ} \mathrm{C}$ in a humidified atmosphere of $5 \% \mathrm{CO}_{2}$.

Disc-shaped specimens $(5 \times 1 \mathrm{~mm})$ were prepared for each material $(n=10)$. The specimens were immersed in $1 \mathrm{~mL}$ of Dulbelcco's modified Eagle's medium (DMEM) in 96-well microplates and incubated in a $10 \% \mathrm{CO}_{2}$ atmosphere at $37^{\circ} \mathrm{C}$ and $100 \%$ relative humidity for 24, 72 and 168 hours. After each period, the specimens were removed and the eluate filtered (0.22 $\mu \mathrm{m}$, Millex, Milipore, São Paulo, Brazil). The eluates obtained were then used in the experiments to determine cell viability.
Two hundred $\mu \mathrm{L}$ of the eluate from each specimen were then transferred to the 96-well plate containing the pre-cultured cells. The plate was then incubated $\left(37^{\circ} \mathrm{C}, 5 \% \mathrm{CO} 2\right)$ for a period of $24 \mathrm{~h}$. After this period, the medium was aspirated, and then $180 \mu \mathrm{L}$ of DMEM with $20 \mu \mathrm{L}$ of MTT solution were added to each well of the 96 -well plates. After $4 \mathrm{~h}$ of incubation at $37^{\circ} \mathrm{C}$ in darkness, the medium was discarded. Afterwards, $200 \mu \mathrm{L}$ of dimethyl sulfoxide were added and the formazan was solubilized on a shaker for $5 \mathrm{~min}$ at $150 \mathrm{rpm}$. The absorbance of each well was evaluated in a microplate reader (MR-96A, Mindray Shenzhen, China) at a wavelength of $540 \mathrm{~nm}$. MTT assay were repeated in three separate experiments.

\section{Genotoxicity assay (Micronuclei test)}

3T3/NIH fibroblasts $\left(4 \times 10^{4} \mathrm{cell} / \mathrm{mL}\right)$ were cultivated in circular glass slides of $13 \mathrm{~mm}$ diameter in 24-well plates in $400 \mu \mathrm{L}$ cell culture medium for $24 \mathrm{~h}$ at $37^{\circ} \mathrm{C}$ and $5 \% \mathrm{CO}_{2}$. The cell culture medium was replaced by the eluate formed after specimens incubation for 24, 72 and 168 hours.

After this period, cells were detached again using $0.15 \%$ trypsin for $5 \mathrm{~min}$. Then, the cells were fixed on glass slides in 3:1 methanol/acetic acid for $30 \mathrm{~min}$. The cells were dried and lysed in $1 \mathrm{~N}$ $\mathrm{HCl}$ for $40 \mathrm{~min}$. DNA-containing structures were stained with Schiff's reagent for $2 \mathrm{~h}$ and $30 \mathrm{~min}$ at room temperature in darkness. Afterwards, the glass slides were rinsed in distilled water and dried again. Then, the glass slides were immersed in Fast Green for 10s and washed three times in ethanol. The light microscopic assessment of coded slides was done in 400x magnification.

A total of 1000 cells per preparation were analyzed. Micronuclei were identified as DNA-containing structures in the cytoplasm, separated from the main nucleus, and with an area smaller than $1 / 3$ of the main nucleus, according to the criteria described by Countryman and Heddle.

\section{Physical-mechanical assays}

\section{Water sorption and solubility}

Water sorption and solubility of the materials were evaluated in accordance with the specifications 
established in ISO No. 4049 International Standard, except for the specimen dimensions. ${ }^{7}$ Disc-shaped specimens $(5 \times 1 \mathrm{~mm})$ were fabricated for each material $(n=10)$. Immediately after setting, the specimens were placed in a vertical support inside a desiccator. They were weighed daily until their mass remained constant (mass loss of each specimen is not more than $0.1 \mathrm{mg}$ in any $24 \mathrm{~h}$ period); this mass was registered as $m_{1}$. After obtaining $m_{1}$, the thickness and diameter values of the specimens were randomly measured at 5 points using a digital caliper, with the values rounded to the nearest 0.01 $\mathrm{mm}$. From these measurements, the volume (V) of each specimen was expressed in $\mathrm{mm}^{3}$. The discs were then immersed in distilled water at $37^{\circ} \mathrm{C}$ for 7 days, removed, blotted dry, and re-weighed $\left(m_{2}\right)$. Thereafter, the specimens were again dried inside a desiccator and weighed daily to record a third constant mass $\left(m_{3}\right)$, as previously described. For each disc, the data for water sorption (WS) and solubility (SL) were calculated, in $\mu \mathrm{g} / \mathrm{mm}^{3}$, using the following formulas:

$$
W S=\frac{\left(m_{2}-m_{3}\right)}{V} \quad S L=\frac{\left(m_{1}-m_{3}\right)}{V}
$$

\section{Ultimate tensile strength (UTS)}

Dumbell-shaped specimens $(10 \mathrm{~mm}$ long $\mathrm{x}$ $10 \mathrm{~mm}$ wide $\times 1 \mathrm{~mm}$ thick) with a cross-sectional constriction area of $\pm 1.0 \mathrm{~mm}^{2}$ were produced by using a metallic mold. Fifteen dumbbell-shaped specimens were made only for light-cured periodontal dressing (Barricaid ${ }^{\circledR}$ and Exothane based). Periobond ${ }^{\circledR}$ was not included in this analysis because the set material is brittle, in this way, it was not possible to produce specimens. After removing from the mold, the area of the constriction zone was measured with a digital caliper and then, the specimens were dry-stored for $24 \mathrm{~h}$ at room temperature. After this period, specimens were fixed in a metallic device with cyanoacrylate-based glue and tested by ultimate tensile strength in a universal testing machine (EMIC DL 500) at a $0.5 \mathrm{~mm} / \mathrm{min}$ crosshead speed until fracture. The cohesive strength was calculated, in $\mathrm{MPa}$, by dividing the maximal load at failure by the cross-sectional area of the bond interface.

\section{Statistical analysis}

The statistical analysis was performed using the Sigma Plot 14.0 Software (Systat Software Inc. GmbH, Erkrath, Germany). Data were analyzed to test the assumption of normal distribution and homogeneity of variance. One-way ANOVA was used to detect the presence of statistically significant differences among the groups. For UTS, data failed the normality and equality of variance, then, a non-parametric Kruskal Wallis test was used. Tukey's post-hoc test was used to identify statistical differences among the groups. In all cases, the level of significance was set to $\alpha<0.05$.

\section{Results}

The cell viability of the periodontal dressings tested, as a function of the different times of eluate extraction is presented in the Figure 1. All the materials promoted a cell viability lower than $60 \%$ in all times. In general, the cell viability was significantly reduced after 72 and 168 h of specimens' incubation $(p<0.05)$. All tested materials showed high values of coefficient of determination (Exothane: 0.871; Barricaid $^{\oplus}$ : 0.987; Periobond ${ }^{\oplus}: 0.739$ ), but these were not statistically significant (linear regression model, $\mathrm{p}>0.05)$.

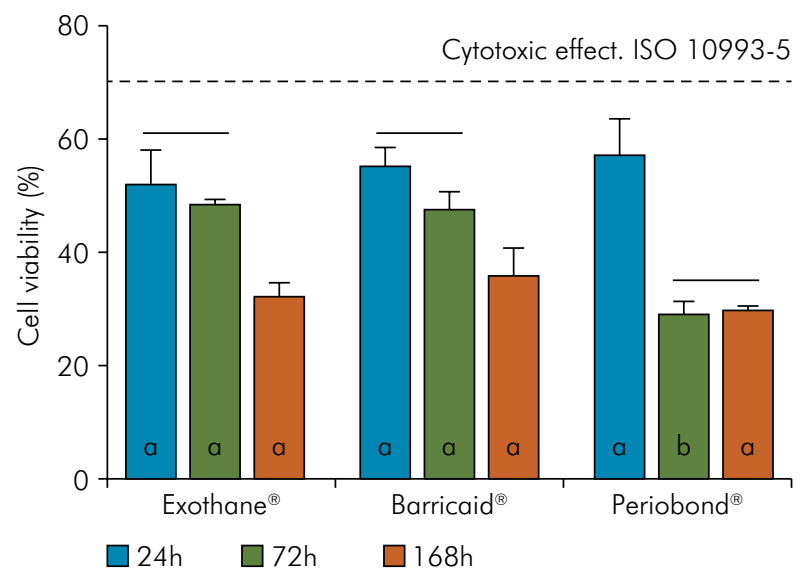

Figure 1. Cell viability of periodontal dressings after exposure to $24 \mathrm{~h}, 72 \mathrm{~h}$, or $168 \mathrm{~h}$ eluates. Columns under the same horizontal line indicate no differences between specimen's incubation period for each period material. Different lowercase letters indicate differences between materials within each specimen's incubation period. 
The genotoxicity data of the eluates obtained after 7, 24 and 168 hours of incubation are shown in Figure 2. There was no statistically significant difference among the groups in the different periods of time ( $p>0.05)$. Considering the factor material, there were also no differences in the genotoxicity of the periodontal dressings ( $p>0.05$ ).

The values of UTS are expressed in Figure 3. According to the analysis, there was no statistically significant difference among the groups $(p=0.125)$ Water sorption and solubility results are shown in Table 2. Concerning water sorption, Periobond ${ }^{\circledR}$ showed statistically higher water sorption values $(\mathrm{p}<0.001)$, while there were not statistically significant differences between Barricaid ${ }^{\circledR}$ and Exothane-based materials. Regarding solubility, there were no statistical differences between the groups $(p=0.098)$.

\section{Discussion}

In this study, the biological and mechanical characterization of different periodontal dressing materials was performed. An experimental material based on Exothane ${ }^{\circledR} 8$ was formulated and its characteristics were compared with two commercially available periodontal dressing materials, Barricaid ${ }^{\circledR}$ and Periobond ${ }^{\circledast}$. The results obtained suggested that some of the evaluated properties were material

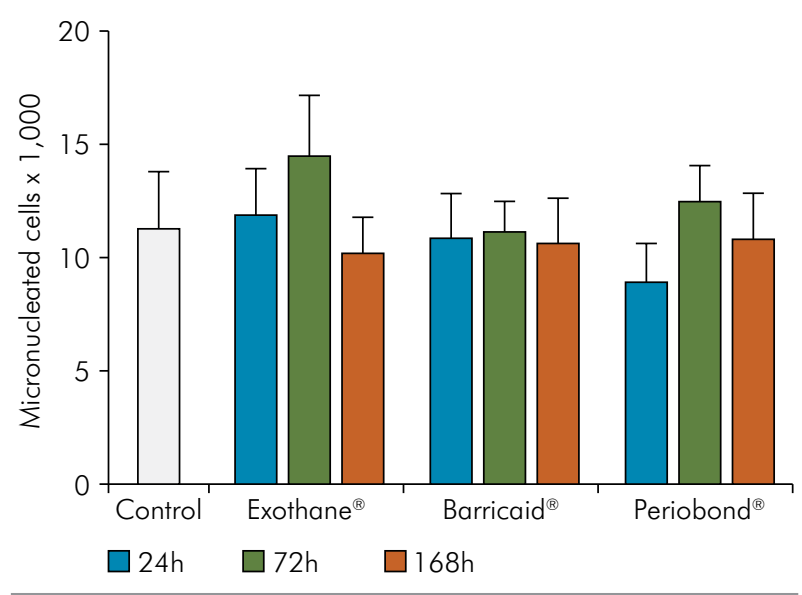

Figure 2. Number of micronucleated cells (MN) per 1,000 cells after after exposure to $24 \mathrm{~h}, 72 \mathrm{~h}$, and $168 \mathrm{~h}$ eluates of periodontal dressing. All comparisons resulted in the absence of statistically significant differences $(p>0.05)$. dependent, then, the null hypothesis tested was partially rejected.

Biological outcomes from periodontal dressing materials were assessed through the cytotoxicity and genotoxicity assays. These tests are commonly used for the initial assessment of the toxic effects of dental materials, presiding the pre-clinical and clinical evaluation. ${ }^{8,9,10}$ One important factor for the delineation of in vitro cytotoxic test is the choice of an adequate cell line related with the intended application of the material. ${ }^{11,12}$ In this study, periodontal dressings were tested against fibroblasts, since connective tissue is the most frequently protected tissue by surgical dressings in periodontal surgeries and to follow recommendations from the ISO 10993-5.10 Consequently, being fibroblasts also the most abundant cell in periodontal tissues,$^{13}$ the choice of an immortalized fibroblast cell lines was preferred due to a higher rate of cell multiplication and prolonged life span compared to primary culture cells, resulting in high reproducibility of results.

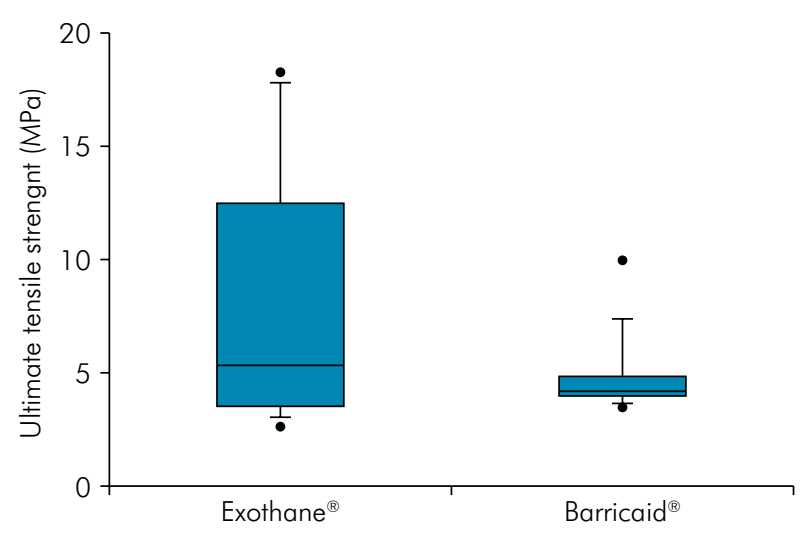

Figure 3. Ultimate tensile strength for Exothane-based and Barricaid ${ }^{\circledR}$ periodontal dressings. There were not statistically significant differences among the materials $(p=0.063)$.

Table 2. Water sorption and solubility, mean and standard deviation in $\mu \mathrm{g} / \mathrm{mm}^{3}$ ( $\left.\mathrm{n}=10\right)$.

\begin{tabular}{lcc}
\hline Groups & WS & SL \\
\hline Periobond $^{\circledR}$ & $426.0(240.9)^{\mathrm{a}}$ & $6.7(3.6)^{\mathrm{a}}$ \\
Barricaid $^{\circledR}$ & $83.5(29.8)^{\mathrm{b}}$ & $4.3(1.7)^{\mathrm{a}}$ \\
Experimental $^{\mathrm{a}}$ & $46.6(12.9)^{\mathrm{b}}$ & $6.8(2.7)^{\mathrm{a}}$ \\
\hline
\end{tabular}

Groups with different overlapping letters indicate statistically significant differences $(p<0.001)$. 
Regarding cell viability, according to ISO 10993-5, all materials should be considered as cytotoxic. ${ }^{10}$ Also, the results suggest that for each material, this property was time dependent; the cell viability was reduced after 72 and 168 hours of specimen incubations. For experimental Exothanebased and Barricaid ${ }^{\circledR}$ periodontal dressings, this behavior could be explained due to the polymeric nature of the materials. It is well known that during the polymerization of light-curing resin-based materials, most of the monomers should be converted into polymers, however, some monomers remain unreacted within the polymeric matrix, affecting the biocompatibility outcomes. ${ }^{14}$ Actually, the release of unreacted substances from the material to the oral media is related to a decrease in the cell viability. ${ }^{15}$ The release of unreacted substances from resin-based materials has been thoroughly studied, and despite the lack of accurate and standardized analytical research ${ }^{16}$ there exist evidence that the maximal concentrations of unreacted substances are observed in the long-term. ${ }^{17}$ For the resin-based periodontal dressing materials evaluated in this study, this behavior can also be explained by the relatively high elasticity of the materials, since the less rigid the polymer network the more the swelling is expected and, consequently, the more the release of unreacted substances. ${ }^{18}$

Among the released substances from resinbased periodontal dressings that can be associated to the cytotoxic effect, we could find, according to the formulation of the materials, urethane dimethacrylates and photoinitiators. Previously, it has been demonstrated that urethane dimethacrylates monomers are toxic to gingival fibroblasts. ${ }^{19,20,21}$ These reports indicate that this monomer may trigger various toxic mechanisms, like cellular glutathione depletion and membrane damage, which eventually leads to apoptosis. With regards to the release of photoinitiators and its potential cytotoxicity, the scientific evidence is scarce. Few studies have been reported the cytotoxicity induced by camphorquinone, ${ }^{22,23,24,25}$ and despite the mechanism responsible for CQ is not well known, it has been reported to be dose-dependent.

Periobond ${ }^{\circledR}$ also exerted cytotoxicity against fibroblast cells. This effect may be partially caused by the released of some of its components into the incubation medium. Previous reports have demonstrated that the release of zinc, rosin or resin acids from non-eugenol periodontal dressings have a direct effect on the presence of cellular alterations of gingival fibroblasts and especially 3T3-cells. ${ }^{26,27,28}$ Also, according to our results, the toxicity of Periobond ${ }^{\circledast}$ became more apparent over time, however, more studies should be performed to corroborate this.

The genotoxicity of periodontal dressing materials was also evaluated. Genotoxicity tests are designed to detect compounds that induce genetic damage by various mechanisms, including chromosome breakage, chromosome loss, chromosome rearrangement, inhibition of cell division, apoptosis and necrosis. ${ }^{29}$ According to the results, the genotoxicity observed for the eluted components released by the periodontal-dressing materials was not significantly different than the observed for the DMEM alone used as control. The lack of studies regarding the genotoxicity from periodontal dressing materials limits the discussion. Actually, a recently published review regarding genotoxicity induced by dental materials does not include any of the materials evaluated in our study. ${ }^{9}$ Despite this, the behavior of light-cure dressing materials evaluated in this study can be explained by analyzing the genotoxicity of their individual components, specially the urethane dimethacrylate monomer, where a study found that this compound did not induce strand breaks in an isolated plasmid DNA..$^{30}$

This study also evaluated the ultimate tensile strength of periodontal dressing materials. It should be noted that, until date, few studies have compared the physical-mechanical characteristics of these materials, ${ }^{31,32,33}$ this is in part due to the lack of standardized characterization techniques to evaluate them. With regards to ultimate tensile strength, only Barricaid ${ }^{\circledR}$ and the experimental Exothane ${ }^{\circledR}$ based periodontal dressing were evaluated. This mechanical property is frequently used to evaluate the performance of a dental material in terms of its tensile bond strength with the local tissues. ${ }^{34}$ If we consider that after periodontal surgery, oral cavity is steadily undergone mechanical insult constantly that may lead to treatment failure, ${ }^{2}$ the need of a 
periodontal dressing with optimal mechanical properties that would protect the wound is highly desirable. In this sense, considering the absence of statistically significant differences among the materials evaluated, the experimental periodontal dressing formulated in this study would have a similar clinical performance than the Barricaid ${ }^{\circledR}$ material.

Finally, the hygroscopic behavior of periodontal dressings was assessed through the water sorption and solubility tests. Considering the results, it was possible to determine that the Periobond ${ }^{\circledR}$ material achieved the highest values of water sorption. This behavior could be the result of the large amount of hydrophilic materials within the set material, which could have allowed an ingress of water. ${ }^{35}$ As water absorption induces expansion of the material, this phenomenon could have promoted the release of a large number of unreacted components, which in turn may have caused the high cytotoxicity values observed for this material. The absorption of water by the material may also result in a weight and volume increase, which is not desirable for materials that should remain effective over an extended period of clinical use. ${ }^{36}$ The high water sorption for Periobond ${ }^{\circledR}$ may also be related with absorption of odors, support of bacteria, and color changes. ${ }^{37}$ Considering the large amount of water absorbed by this material, one might expect a higher solubility rate, however, this was not observed in our study. Since there were no statistical significant differences among the materials ( $p=0.098)$, one can assume that
Periobond ${ }^{\circledR}$ material retained water in its structure and thus the loss of mass due to dissolution was compensated..$^{38}$

This study is not free of limitations and an in vitro cell culture may not represent an in vivo surgical wound. Surgical sites comprise multiple cell types, which are activated by local and systemic inflammatory reactions, all affecting wound healing. Therefore, in vivo studies comparing these materials are necessary. Human progenitor cells in wound sites can regenerate, while cells grown in monolayers have limited regeneration capability. On the other hand, controlled in vitro studies allows for better quantitative analysis without interference of in vivo factors and, thus, are proposed as an initial step for toxicity studies.

\section{Conclusion}

All the periodontal dressing materials evaluated in this study exerted a cytotoxic effect against mouse fibroblasts, and their toxicity became more evident over time. The experimental periodontal cement with Exothane showed biocompatibility and mechanical outcomes similar to the commercial references, and can be considered as an alternative for the formulation of novel periodontal surgical dressings.

\section{Acknowledgments}

We thank Fabricio Aulo Ogliari for the discussions on the properties of Exothane along the study.

\section{References}

1. Baghani Z, Kadkhodazadeh M. Periodontal dressing: a review article. J Dent Res Dent Clin Dent Prospects. 2013;7(4):183-91. https://doi.org/10.5681/joddd.2013.040

2. Monje A, Kramp AR, Criado E, Suárez-López Del Amo F, Garaicoa-Pazmiño C, Gargallo-Albiol J, et al. Effect of periodontal dressing on non-surgical periodontal treatment outcomes: a systematic review. Int J Dent Hyg. 2016 Aug;14(3):161-7. https://doi.org/10.1111/idh.12130

3. Kathariya R, Jain H, Jadhav T. To pack or not to pack: the current status of periodontal dressings. J Appl Biomater Funct Mater. 2015 Jul;13(2):e73-86. https://doi.org/10.5301/jabfm.5000215

4. Sarrami N, Pemberton MN, Thornhill MH, Theaker ED. Adverse reactions associated with the use of eugenol in dentistry. Br Dent J. 2002 Sep;193(5):257-9. https://doi.org/10.1038/sj.bdj.4801539

5. Madan E, Bharti V, Chaubey KK, Arora VK, Thakur RK, Nirwal A. Light-cured resin "Barricaid" - An aesthetic and biocompatible dressing: A step ahead. J Indian Soc Periodontol. 2013 Nov;17(6):753-6. https://doi.org/10.4103/0972-124X.124494

6. Kumar MB, Narayanan V, Jalaluddin M, Almalki SA, Dey SM, Sathe S. Assessment of clinical efficacy of different periodontal dressing materials on wound healing: A comparative study. J Contemp Dent Pract. 2019 Aug;20(8):896-900. https://doi.org/10.5005/ip-journals-10024-2631 
- Biological and mechanical characterization of commercial and experimental periodontal surgical dressings

7. International Organization for Standarization - ISO. ISO 4049:2009 Dentistry Polymer based restorative materials. Geneva: International Organization for Standarization; 2009.

8. Murray PE, García Godoy C, García Godoy F. How is the biocompatibilty of dental biomaterials evaluated? Med Oral Patol Oral Cir Bucal. 2007 May;12(3):E258-66.

9. Ribeiro DA, Yujra VQ, DE Moura CF, Handan BA, DE Barros Viana M, Yamauchi LY, et al. Genotoxicity induced by dental materials: a comprehensive review. Anticancer Res. 2017 Aug;37(8):4017-24. https://doi.org/10.21873/anticanres.11786

10. International Organization for Standardization - ISO. ISO 10993-5:2009 Biological evaluation of medical devices — Part 5: Tests for in vitro cytotoxicity. Geneva: International Organization for Standardization; 2009.

11. Bolt HM. Highlight report: cell type selection for toxicity testing. EXCLI J. 2018 Dec;17(17):1180-1. https://doi.org/10.17179/excli2018-2017

12. Geraghty RJ, Capes-Davis A, Davis JM, Downward J, Freshney RI, Knezevic I, et al. Guidelines for the use of cell lines in biomedical research. Br J Cancer. 2014 Sep;111(6):1021-46. https://doi.org/10.1038/bjc.2014.166

13. Kumada Y, Zhang S. Significant type I and type III collagen production from human periodontal ligament fibroblasts in 3D peptide scaffolds without extra growth factors. PLoS One. 2010 Apr;5(4):e10305. https://doi.org/10.1371/journal.pone.0010305

14. AlShaafi MM. Factors affecting polymerization of resin-based composites: A literature review. Saudi Dent J. 2017 Apr;29(2):48-58. https://doi.org/10.1016/i.sdentj.2017.01.002

15. Toz T, Kiremitçi A, Sera Çakmak A, Ünsal Tan O, Palaska E, Gümüşderelioğlu M, et al. A comparative study on monomer elution and cytotoxicity of different adhesive restoration materials. J Adhes Sci Technol. 2017;31(4):414-29. https://doi.org/10.1080/01694243.2016.1215768

16. Van Landuyt KL, Nawrot T, Geebelen B, De Munck J, Snauwaert J, Yoshihara K, et al. How much do resin-based dental materials release? A meta-analytical approach. Dent Mater. 2011 Aug;27(8):723-47. https://doi.org/10.1016/i.dental.2011.05.001

17. Örtengren $\mathrm{U}$, Wellendorf H, Karlsson S, Ruyter IE. Water sorption and solubility of dental composites and identification of monomers released in an aqueous environment. J Oral Rehabil. 2001 Dec;28(12):1106-15. https://doi.org/10.1046/j.1365-2842.2001.00802.x

18. Sideridou I, Tserki V, Papanastasiou G. Study of water sorption, solubility and modulus of elasticity of light-cured dimethacrylate-based dental resins. Biomaterials. 2003 Feb;24(4):655-65. https://doi.org/10.1016/S0142-9612(02)00380-0

19. Moharamzadeh K, Van Noort R, Brook IM, Scutt AM. Cytotoxicity of resin monomers on human gingival fibroblasts and HaCaT keratinocytes. Dent Mater. 2007 Jan;23(1):40-4. https://doi.org/10.1016/i.dental.2005.11.039

20. Volk J, Engelmann J, Leyhausen G, Geurtsen W. Effects of three resin monomers on the cellular glutathione concentration of cultured human gingival fibroblasts. Dent Mater. 2006 Jun;22(6):499-505. https://doi.org/10.1016/i.dental.2005.06.002

21. Geurtsen W, Lehmann F, Spahl W, Leyhausen G. Cytotoxicity of 35 dental resin composite monomers/additives in permanent 3T3 and three human primary fibroblast cultures. J Biomed Mater Res. 1998 Sep;41(3):474-80. https://doi.org/10.1002/(SICI)1097-4636(19980905)41:3<474::AID-JBM18>3.0.CO;2-I

22. Atsumi T, Ishihara M, Kadoma Y, Tonosaki K, Fujisawa S. Comparative radical production and cytotoxicity induced by camphorquinone and 9-fluorenone against human pulp fibroblasts. J Oral Rehabil. 2004 Dec;31(12):1155-64. https://doi.org/10.1111/j.1365-2842.2004.01357.x

23. Chang MC, Lin LD, Wu MT, Chan CP, Chang HH, Lee MS, et al. Effects of camphorquinone on cytotoxicity, cell cycle regulation and prostaglandin E2production of dental pulp cells: role of ROS, ATM/Chk2, MEK/ERK and hemeoxygenase-1. PLoS One. 2015 Dec;10(12):e0143663. https://doi.org/10.1371/journal.pone.0143663

24. Van Landuyt KL, Krifka S, Hiller KA, Bolay C, Waha C, Van Meerbeek B, et al. Evaluation of cell responses toward adhesives with different photoinitiating systems. Dent Mater. 2015 Aug;31(8):916-27. https://doi.org/10.1016/i.dental.2015.04.016

25. Almeida SM, Meereis CT, Leal FB, Carvalho RV, Boeira PO, Chisini LA, et al. Evaluation of alternative photoinitiator systems in two-step self-etch adhesive systems. Dent Mater. 2020 Feb;36(2):e29-37. Available from: https://doi.org/10.1016/i.dental.2019.11.008

26. Alpar B, Günay H, Geurtsen W, Leyhausen G. Cytocompatibility of periodontal dressing materials in fibroblast and primary human osteoblast-like cultures. Clin Oral Investig. 1999 Mar;3(1):41-8. https://doi.org/10.1007/s007840050077

27. Sunzel B, Söderberg TA, Johansson A, Hallmans G, Gref R. The protective effect of zinc on rosin and resin acid toxicity in human polymorphonuclear leukocytes and human gingival fibroblasts in vitro. J Biomed Mater Res. 1997 Oct;37(1):20-8. https://doi.org/10.1002/(SICI)1097-4636(199710)37:1<20::AID-JBM3>3.0.CO;2-L

28. Nezwek RA, Caffesse RG, Bergenholtz A, Nasjleti CE. Connective tissue response to periodontal dressing. J Periodontol. 1980 Sep;51(9):521-9. https://doi.org/10.1902/jop.1980.51.9.521

29. U.S. Food and Drug Administration. International Conference on Harmonisation guidance on S2(R1) genotoxicity testing and data interpretation for pharmaceuticals intended for human use. Fed Regist. 2012 Jun;77(110):33748-9.

30. Wisniewska-Jarosinska M, Poplawski T, Chojnacki CJ, Pawlowska E, Krupa R, Szczepanska J, et al. Independent and combined cytotoxicity and genotoxicity of triethylene glycol dimethacrylate and urethane dimethacrylate. Mol Biol Rep. 2011 Oct;38(7):4603-11. https://doi.org/10.1007/s11033-010-0593-1 
31. Rubinoff CH, Greener EH, Robinson PJ. Physical properties of periodontal dressing materials. J Oral Rehabil. 1986 Nov;13(6):575-86. https://doi.org/10.1111/j.1365-2842.1986.tb00681.x

32. Gjerdet NR, Haugen E. Dimensional changes of periodontal dressings. J Dent Res. 1977 Dec;56(12):1507-10. https://doi.org/10.1177/00220345770560121701

33. Watts TL, Bertenshaw BW, Combe EC. Initial physical tests of aluminoborate cements in the context of periodontal dressing development. J Oral Rehabil. 1983 Sep;10(5):393-8. https://doi.org/10.1111/i.1365-2842.1983.tb00135.x

34. Takahashi A, Sato Y, Uno S, Pereira PN, Sano H. Effects of mechanical properties of adhesive resins on bond strength to dentin. Dent Mater. 2002 May;18(3):263-8. https://doi.org/10.1016/S0109-5641(01)00046-X

35. Ferracane JL. Hygroscopic and hydrolytic effects in dental polymer networks. Dent Mater. 2006 Mar;22(3):211-22. https://doi.org/10.1016/i.dental.2005.05.005

36. Dinçkal Yanikoglu N, Yeşil Duymuş Z. Comparative study of water sorption and solubility of soft lining materials in the different solutions. Dent Mater J. 2004 Jun;23(2):233-9. https://doi.org/10.4012/dmi.23.233

37. Kawano F, Dootz ER, Koran A 3rd, Craig RG. Sorption and solubility of 12 soft denture liners. J Prosthet Dent. 1994 Oct;72(4):393-8. https://doi.org/10.1016/0022-3913(94)90559-2

38. Lagouvardos PE, Pissis P, Kyritsis A, Daoukaki D. Water sorption and water-induced molecular mobility in dental composite resins. J Mater Sci Mater Med. 2003 Sep;14(9):753-9. https://doi.org/10.1023/A:1025080103857 